\title{
Agricultural Development New Perspectives in a Changing World
}

\section{Edited by Keijiro Otsuka and Shenggen Fan}

\section{Agricultural}

\section{Development}

New Perspectives in

a Changing World

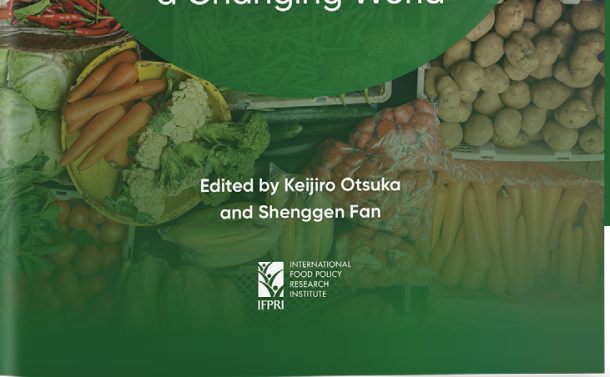

$\mathrm{n}$ recent decades, complex emerging issues including rapid urbanization, agricultural transformation, nutrition and health, gender equity, and climate change have been reshaping how we understand and pursue agricultural development. Traditionally, agricultural development efforts aimed to increase food production and availability, improve agricultural productivity, and raise the incomes of small farmers. Given the rapidly changing global landscape, however, we now know that agricultural development has a major role to play in reducing poverty, ensuring adequate nutrition, creating strong food value chains, improving environmental sustainability, and promoting gender equity and equality.

Agricultural Development: New Perspectives in a Changing World is the first comprehensive volume to address these and other issues facing agriculture today. Divided into four parts, the book brings together top experts to provide a global overview of agriculture, examine regional patterns of development, lay out the current context for agricultural development, and explore emerging challenges and opportunities in the field.

Using new lenses to examine key challenges, contributors delve into topics such as nutrition, household decision-making behavior, trade and food value chains, natural resource management, climate change, agricultural research, and political economy. The book covers most developing countries and regions, providing a much-needed global perspective at a time when many factors affecting agricultural development extend beyond national borders. Tying all this together, Agricultural Development explores possible policy reforms for encouraging agricultural development and strategies for developing sustainable agriculture and reducing food insecurity and malnutrition.

\section{Trends in Agricultural Growth}

Agricultural Development compares patterns of agricultural growth and structural transformation across seven major regions, using induced innovation theories about the role of innovation and productivity. The book looks at land-labor ratios, mechanization, fertilizer use, and numerous other factors that contribute to regional variations in agricultural growth and productivity. It describes varying growth paths over time across the regions. For example, East Asia took a high-land-productivity development path - meaning that land productivity rose faster than labor productivity. South Asia seems to have been following the East Asian path, as does Africa south of the Sahara, at least as long as smallholder-based agriculture is maintained. The growth paths of Latin American and Eastern Europe, where land is more abundant, look similar; however, closer examination reveals that Eastern Europe primarily improved labor productivity, whereas much of Latin America improved land and labor productivity simultaneously. 


\section{Nonfarm Activities and Urbanization}

The nonfarm economy grows faster than does agriculture. This reflects both the low and decreasing income elasticity of demand for agricultural products, and also the ease of technology transfer in nonfarm sectors from developed to developing countries compared with agricultural technology, whose transfer is often constrained by climate factors. The faster growth of nonfarm sectors creates an income gap between rural and urban areas, which drives urbanization and rural-to-urban migration and, consequently, economic transformation. In this process, people shift from low-income jobs in rural areas to high-income jobs in urban areas, thereby reducing the income gap and poverty.

As a result, the share of the rural labor force is declining all over the world. In South Asia and Africa south of the Sahara, rural labor shares were high and have fallen slowly due to the slow growth of nonfarm sectors. In East Asia, however, the successful development of nonfarm sectors caused the rural labor share to decline rapidly. Nevertheless, through the 2010s, the share remained higher in East Asia than in Eastern Europe, the former Soviet countries, and Latin America.

The close linkage between agricultural development and urbanization is illustrated by the expansion of contract farming, which is designed to promote the production of new high-value products, such as fresh produce and meat and dairy, in response to increasing urban and foreign demand. Such new production opportunities can increase rural incomes and reduce poverty. Rural industrialization likewise increases employment opportunities in rural areas. Rural industries tend to cluster geographically because of the benefit of agglomeration, and they are often involved in the processing of high-value products. Together with rural-to-urban migration, the growth of agrifood sector employment through contract farming and rural industries is an important way of facilitating transformation.

Urbanization and economic transformation are closely linked with the diversification of diets - or "nutrition transition" - resulting from shifts in consumer demand that reflect rising incomes and urban lifestyles. Once the classic "food problem" of providing enough calories is solved, adequate nutrition and health become major concerns for agriculture. Agricultural Development explores the linkages between agricultural development and nutrition, including the increasing incidence of obesity. This is particularly important in lower- and middle-income countries, where all forms of malnutrition are highly prevalent among children.

\section{Changes in Markets and Food Value Chains}

In addition to analyzing the role of agriculture in the supply of staple foods, employment generation, poverty reduction, and the nutrition transition, essentially from a sectoral point of view, a number of chapters in the book deal with diverse issues of markets and international trade of agricultural products. The continuous evolution of agricultural development can be seen through the remarkable transformation of food value chains in developing countries, particularly in the past 25 years. The share of grains and other staples in the food economy declined and was replaced by animal and horticultural products. Rapid globalization fundamentally and swiftly changed food value chains in developing countries.

International food trade increased appreciably, driven by liberalization of trade and foreign direct investment (FDI) and increased demand for diverse processed foods and safe and high-quality fresh fruits and vegetables. On the supply side, investments by international chains played a crucial role in transforming food value chains. This is reflected in increasing international trade of agricultural commodities, including high-value perishable products.

Undistorted open markets maximize the net benefit that international trade can offer to boost global food security. However, agriculture in developing countries was long discriminated against by export taxes and restricted import of agricultural inputs, while agriculture in developed countries tends to be heavily protected by subsidies, tariffs, and restricted imports of agricultural products. In other words, farmers are taxed when they are the majority of the population but subsidized when they are the minority. This is referred to as the "development paradox." The book explores the political economy reasons underlying the frequent distortion of agricultural markets throughout much of history and across the globe.

\section{Gender, Credit, and Insurance}

Access to resources - from land to capital to information is fundamental to the success of small farmers. Yet women are often handicapped in ownership and control of agricultural land and other assets in developing countries. Since women tend to devote more resources to children's education, health, and nutrition, their lack of access to productive resources may lead to underinvestment in their human capital. Understanding household behaviors - including the roles of men and women, their decision-making powers, and how much they cooperate within a household - can inform efforts to improve gender equity and investments in child schooling, nutrition, and health.

For all farmers, access to institutional credit is essential for smoothing consumption over time under risky agricultural production environments, financing the purchase of modern inputs such as improved seeds and inorganic fertilizer, introducing new high-value products, and 
investing in land improvements to boost long-term productivity. Yet only a small fraction of farmers borrow from formal institutions, and those funds are used primarily for smoothing consumption, not for raising agricultural productivity. While borrowing from microfinance institutions, which does not require collateral, is encouraged by many developing-country governments and international organizations, these institutions are designed to provide smallscale and short-term lending primarily to nonfarm businesses. Possibilities for creating more effective institutions to provide credit to smallholders, which would accelerate agricultural development, are explored in the book.

Also difficult is the design of efficient, effective, and widely acceptable insurance programs. Traditional crop insurance programs, designed to insure farm-specific losses, are rarely viable for small farmers in developing countries, in part because of moral hazard (when insured farmers do not exert optimum efforts to reduce risk or mitigate its impact) and adverse selection (when only risky farmers purchase insurance) but also because of the high costs of insuring small producers. Recently, index insurance programs have been promoted as a low-cost alternative to traditional insurance. In the case of index insurance products, payments are based on an independent measure, like rainfall, that is highly correlated with farm-level yield or revenue outcomes. Since rainfall is exogenous to the individual insurance policyholder, there is no incentive for a farmer to commit moral hazard. Although high expectations for the wide adoption of index insurance have not panned out, there are ways to make insurance programs work in developing countries, as chapters in Agricultural Development show.

\section{Climate Change and Sustainable Development} of Agrifood Systems

Achieving sustainable agricultural development without sacrificing environmental quality is one of the most important challenges in today's world, especially if we are to achieve poverty reduction, food security, and better nutrition and health. The global environment, however, has been deteriorating, and climate change is expected to cause a substantial reduction in agricultural production unless adequate investments are made in productivity-enhancing technological development. Efforts to expand agricultural areas in developing countries have resulted in deforestation, a major source of greenhouse gas emissions. Communal natural resources, such as forests, grazing land, and irrigation systems, also suffer from deterioration. In total, agriculture, forestry, and other land uses account for almost a quarter of greenhouse gas emissions. Also worrisome is increasing water scarcity due to rising demand for water in industrialized and urban areas, dietary changes toward more water-intensive foods, and frequent droughts associated with climate change.
As Agricultural Development shows, we must strengthen our ability to mitigate and reduce environmental deterioration and to use natural resources more efficiently. Agricultural research will be critical for adaptation to climate change. Adaptation can benefit from the use of biotechnologies - for example, gene editing - to develop crop varieties that are tolerant to heat, drought, salinity, and submergence as well as agronomic practices that use new varieties effectively. Investment in irrigation is also an integral part of any adaptation strategy, because the availability of irrigation water enhances resilience to frequent droughts. Currently, the irrigation ratio is particularly low in low-income regions. For more effective adaptation to climate change, greater investments in irrigation will be required.

For sustainable resource management at a global scale, it is essential to reduce the cost of measuring, monitoring, and verifying the use of natural resources and greenhouse gas emissions. An international system is needed to determine penalties for resource use and greenhouse gas emissions and to enforce payments. Increasing the cost of natural resource use should contribute not only to more efficient allocation of such resources in the short term, but also to the development of natural-resource-saving technologies in the long term. The agricultural sector must contribute to solving climate change by constructing the proper incentive systems in natural resource use and inducing the development of natural-resource-saving technologies to achieve the critical goal of sustainable agricultural development.

\section{Looking Ahead}

In the coming years, agriculture will continue to face new and escalating challenges and must be positioned to deliver broader development outcomes such as those mandated under the Sustainable Development Goals. Agrifood systems are already undergoing remarkable changes, reflected in the modernization of food value chains and rural transformation. The better we understand these changes, the greater our chances of harnessing agriculture to contribute to a wide range of development goals that extend beyond agricultural productivity growth and food security. To this end, Agricultural Development: New Perspectives in a Changing World has brought together top experts to explore the most critical issues in the field today, making it an indispensable resource for policymakers, researchers, and students dedicated to improving agriculture for global wellbeing. 


\section{Part I: A Global Overview of Agriculture}

Chapter 1 Agricultural Development in a Changing World

Shenggen Fan and Keijiro Otsuka

Chapter 2 Global Issues in Agricultural Development

Mark W. Rosegrant, Shenggen Fan, and Keijiro Otsuka

\section{Part II: Regional Issues in Agricultural Development}

Chapter 3 Changing Farm Size and Agricultural Development in East Asia

Futoshi Yamauchi, Jikun Huang, and Keijiro Otsuka

Chapter 4 Agricultural Development and Modernization in South Asia Hiroyuki Takeshima, Anjani Kumar, Akhter U. Ahmed, and P. K. Joshi

Chapter 5 Africa's Unfolding Agricultural Transformation

Ousmane Badiane, Xinshen Diao, and Thomas Jayne

Chapter 6 Duality, Urbanization, and Modernization of Agrifood

Systems in Latin America and the Caribbean

Eugenio Díaz-Bonilla and Ruben G. Echeverría

Chapter 7 Agricultural Development and Food Security in Eastern

Europe and Central Asia

Saule Burkitbayeva, William Liefert, and Johan Swinnen

Chapter 8 Regional Experiences: What Have We Learned?

Keijiro Otsuka and Shenggen Fan

\section{Part III: Context for Agricultural Development}

Chapter 9 Agricultural Growth, Urbanization, and Poverty Reduction

Paul Dorosh and James Thurlow

Chapter 10 Agriculture and Undernutrition

Derek Headey and William A. Masters

Chapter 11 Transformation of the Rural Economy

Keijiro Otsuka and Xiaobo Zhang
Chapter 12 Food Value Chain Transformation in Developing Regions

Thomas Reardon and Bart Minten

Chapter 13 Agricultural Development and International Trade

Kym Anderson and Will Martin

Chapter 14 The Political Economy of Agricultural and Food Policies

Johan Swinnen

Chapter 15 Gender, Household Behavior, and Rural Development Cheryl Doss and Agnes Quisumbing

Chapter 16 Credit for Agricultural Development

Shahidur R. Khandker

Chapter 17 Agricultural Insurance for Development: Past,

Present, and Future

Miguel Robles

Chapter 18 Natural Resource Management and Resource Rights for Agriculture

Frank Place, Ruth Meinzen-Dick, and Hosaena Ghebru

\section{Part IV: Emerging Challenges and Opportunities in} Agricultural Development

Chapter 19 Climate Change and Agricultural Development Mark W. Rosegrant, Keith Wiebe, Timothy B. Sulser, Daniel Mason-D'Croz, and Dirk Willenbockel

Chapter 20 The Role of Water in Supporting Food Security: Where We Are and Where We Need to Go Claudia Ringler, Nicostrato Perez, and Hua Xie

Chapter 21 Future of Agricultural Research

David Zilberman

Chapter 22 Reshaping Agrifood Systems to Achieve Multiple Development Goals

Shenggen Fan and Keijiro Otsuka

Agricultural Development: New Perspectives in a Changing World is available for free download at https://doi.org/10.2499/9780896293830

Keijiro Otsuka is a professor of Development Economics at the Graduate School of Economics, Kobe University, Japan, and a chief senior researcher at the Institute of Developing Economies, Tokyo. Shenggen Fan is a chair professor, College of Economics Management, and dean of the Academy of Global Food Economics and Policy at China Agricultural University, Beijing, and former director general of the International Food Policy Research Institute (IFPRI), Washington, DC.

This synopsis is based on the peer-reviewed book Agricultural Development: New Perspectives in a Changing World, published by the International Food Policy Research Institute. Any opinions stated in this book are those of the authors and are not necessarily representative of or endorsed by IFPRI.

Synopsis DOI: https://doi.org/10.2499/9780896293854

INTERNATIONAL FOOD POLICY RESEARCH INSTITUTE

A world free of hunger and malnutrition

IFPRI is a CGIAR Research Center

1201 Eye St, NW, Washington, DC 20005 USA | T. +1-202-862-5600 | F. +1-202-862-5606 | Email: ifpri@cgiar.org | www.ifpri.org | www.ifpri.info 